\begin{tabular}{|c|c|}
\hline & $\begin{array}{l}\text { International Journal of Trend in Scientific } \\
\text { Research and Development (IJTSRD) }\end{array}$ \\
\hline 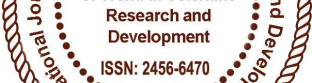 & International Open Access Journal \\
\hline 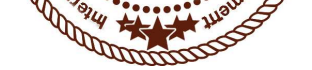 & ISSN No: 2456 - 6470 | www.ijtsrd.com | Volume - 2 | Issue - 2 \\
\hline
\end{tabular}

\title{
Benchmarking Educational Institute: A need of an hour
}

\author{
Dr. Adv. Neeta Deshpande \\ Asst. Professor, V.P. Institute of Management Studies and \\ Research, Sangli affiliated to Shivaji, University Kolhapur, Maharashtra, India
}

\begin{abstract}
There was news that IISC Bangalore has stood the top of National Institutional Raking Framework based on their academic performance. Indian Universities are not at par to attract the foreign students. Only $70 \%$ of the graduates from higher educational institutes are unemployable. We are all aware that the Indian education system has numerous challenges.
\end{abstract}

Then there is need to know if students are learning the right things?. At the right time?, Is there a need to set the standards for education?. Are the students are capable to seek the job of their dream?. Are the students aspiring for starting their own venture?. Is institutions are inculcating entrepreneurial values among the students?. These are the main questions surrounding the practice of benchmarking in education in India. This article focuses on the efforts to be taken to become a benchmarking educational system, institute, practice.

Keywords: IISC, Benchmarking Educational System,

\section{Introduction:}

In India the constitutional provision has offered the free and compulsory education for children aging between 6 and 14 under article 21A. Compulsory education is an obligation on appropriate government and local authorities to provide admission maintain attendance, completion of elementary education. Children will automatically promote to $9^{\text {th }}$ class. Directly they will become serious in matriculate exam only. Then in college, bombarding of different subject at graduate level, students changing attitude, exam

oriented study, faulty assessment process etc result into lack of employability skills among the students. There is big gap between students exiting skills among the students and the industry expectations. The graduates and post graduate students possess their degrees, but they don't have an expected job opportunity. To overcome this situation, there is a need to take efforts to bring our education system as per the global quality standards.

\section{Concept of Benchmarking:}

The concept of 'Benchmarking' was coined by the Xerox Corporation, USA. It is originated with one incident. In those days, Xerox was having a severe competition from Japanese photocopier companies, this endangered Xerox's survival in USA in mid 1970. Since then, the word became the buzz world for quality assessment in the technological and industrial world.

Benchmarking is a systematic, organized and continuous process that helps organizations or institutions to identify and define global quality standards, and define the goals as per their needs and set processes within organization to stay on par with these dynamic goals. The objectives of benchmarking include identifying world-class performance in education, quality enhancement, enhancing expected skills among the students, best practices of teaching and learning, research of faculties etc. 


\section{Educational Benchmarking:}

In case of educational field, benchmarking is related to many fields such as enquiry management, enrolment of students, teaching-learning method, and employability among students, university rankers, precious alumni, best practices, research environment and student's achievement in curricular and extracurricular activities etc. Benchmarking in education occurs when some standards are set for learning. Its rational is to master in each grade. These are used to see where a particular student, class or even school ranks in comparison to others.

\section{Need of Benchmarking in education:}

Small countries have become developed countries, mainly because of their good educational measures. Countries like India with 130 crore population, can we say there is any world class university in our country? Despite the presence of the prestigious IITs and IIMs, Indian educational institutions and universities have had a remarkably poor run when it comes to global institutional rankings. Not a single university is in the global raking of first 200 universities in India.

India is considered as low income economy. The per capita income, standard of living of the people is low than the other developed companies. Many factors are responsible for this situation but poor and sub standard universities are the main reason. The students are graduate, post graduate but they are not able to seek the job in their liking field?. Who are responsible for this scenario?

In some institutes the students are brilliant, faculty is committed and infrastructural facilities are abundant. Then to they are facing problems in placing their students in companies. Why the students are not employable?. Especially in management institutes where UGC grants are not available, the payment of salaries is managed through the fees collected by the students. Those staff members are working well. They are conducting lectures. Our rules and regulations, have bound hands of academicians such that they cannot perform to the best of their abilities. Every institution must have global vision and mission. But due to lack of good policies and practices and lack of collective vision, mission and ambition to become a bench marking educational system, students are the victims.
Government of India has started different schemes like make in India, Start Ups, Research Parks, Skill India, Smart Cities and many others. All these government efforts are for enhancing the educational quality and develop the economy. There is a need to find out the ways and means to transform the teachers, institutes and universities in to world class. If we are unable to make our universities world class and lacking in providing the job opportunities as per the expectations of the aspirants in different fields, again the government will face the big problem of brain drain. Young brilliant students will go abroad, out of them many may not return to their mother countries. No doubt brain drain is having two sides, but the unfavorable side is more strong which will impact severely on Indian economy.

In India two institutions, the IIS i.e. the Indian Institute of Science, Bangalore and the IIT Delhi are the renowned and top rankings. Our regional rival China has more than 25 of its educational institutes placed in the top 100 rankings. ${ }^{1}$

\section{Problems in benchmarking educational system:}

Institutions and Universities in India are not preparing their students for employment. At graduate level, very less percentage of students is considered employable. For establishing prestigious institute like Oxford, Harvard, Cambridge would be very difficult. Because all stakeholders are equally responsible to create a brand of any institute. Bright students, excellent faculty members and sufficient and favorable condition are the main requirements. It is said that India's higher education system is third highest in the world after United States and China. But there is a question is it able to produce the requisite number and quality of professionals from our universities.

Our universities have become magnificent examining body instead of creating a better individual equipped to adapt with the challenges in world. In the present scenario, there are many challenges in the Indian education system.

\section{Quality Challenge:}

I do agree that very few institutes like IITs and IIMs, are having excellence to some extent in limited fields. But in case of other educational institutes, there is something wrong with system. There is lack of creativity and slender thought process that is in work. 
It is also important for our universities to participate in this ranking process. For this the educational institutes should look after the appointment of quality faculties, selection criteria, enrollment criteria, teachers: students ratio. Research oriented environment in the institutes, practical oriented education, quality assessment, tie up with industries, placement efforts etc. There is not a single Indian university featured in world's to 200 universities No doubt India has improved its standing in higher education and got ranking in Asia University 2014 rankings with 10 universities in the top 100.

\section{Present Syllabus:}

Indian education system is criticized as it has the outdated syllabus which has not been updated by experienced teachers and industry professionals. Board of studies restructures the syllabus by adding new topics and removing some exiting topics. But gain the syllabus lacks in fulfilling the expectations of industry. The teachers in current system of education focus more on theoretical knowledge. Very few teachers focus on practical applications while teaching the subjects.

The need of the hour is a custom-made industry approved syllabus which should be updated frequently. On behalf of teaching in four walls of classroom, students are to be explored to real world and understand the process of industry, their problems in various functional areas. There is a need to give more stress on learning rather that examination.

\section{Government Interference:}

In Indian education system, there is license based approach which results in lots of corruption. There should be absolutely indiscriminate recruitment policy in educational institutions and universities. The government should give free hand to the universities and let the faculty members, alumni and staff to take decisions about the university in an independent manner. If we consider the top universities of the world like Harvard, Yale, Stanford or MIT, they are all deemed universities where they are having full right to design the curriculum, syllabus as per the regional needs of industries.

\section{Aids and Grants:}

The Indian Government simply does not have the resources to make up for the decades of underinvestment in education. To tackle with this situation, the government allows more private investment in education to cater to the needs of growing population. Some of the Educational institutions of political leaders are running their so called businesses by collected huge fees from the students. Companies are not satisfied with the candidates they have recruited due to lack in required skills. To get rid of this situation, government can offer the tax deduction in income to companies if they are contributing towards boosting the higher education. There is need of collaboration of Indian institutes with Foreign institutions and student exchange programmes should be encouraged and funded.

\section{Lack of Research:}

In all the faculties of higher education, there is lack of research environment among the teachers and students. The reason may be due to lack of funds and support from concerned authorities. Generally students give more importance to getting placed in campus rather than indulge in higher education and research. There is a need to take efforts on inculcating a culture that promotes research, creativity and innovation in our educational institutes. Interdisciplinary research, multidisciplinary research has to be undertaken to solve many of the social problems. As effective $\mathrm{R} \& \mathrm{D}$ works very well in industrial success, it is also important in educational field. It should be a part of the curriculum and students and faculty should be encouraged to publish articles, research papers. There should be E-Cell in an institution and an incubator fund for enhancing entrepreneurship in all universities.

\section{Technology:}

Use of Black board writing is an age old system. In addition to brick and mortar classroom teaching, it is important to use ICT to make education more accessible. The future belongs to the Massive open online courses (MOOC) which has a wider reach to the audience. Many courses are offered for free by professors at the top schools. These are available to a vast and diverse audience across the globe. Here learners' performance can be monitored easily using the data captured during the start of courses. Due to MOOC, both professors and learners get world-wide exposure which will help in improving pedagogical techniques and knowledge sharing. 


\section{Concentration on limited area of career}

Now days parents think that there are prior two disciplines to make the career bright. The fact is that most of the Indian parents educate their children only to earn and seldom to learn. Everyone is trying to make career in Engineering and Medical field. Instead of concentrating on these limited areas, equal focus should be given on other disciplines. There is a growing demand in other sectors like Food and beverage, Retail, Humanities, advertisement, film production, Hospitality, social media, data analytics, forensic science etc. In near future there is a growing need of entrepreneurship and employees. Awareness programmes have to be organized to make aware the society about saturation in some fields, growing job opportunities in other disciplines.

\section{Counseling cell:}

One of the major drawbacks in Indian Higher education system is the lack and access of information. Parents force their children without considering the child's interest. Many of the students take admission for a particular course without setting any goal. After completion of the course they realize that they are having interest in any other field. This situation certainly is wastage of time, money and efforts. The institutions / universities should develop counseling cells just before the admission process starts. This counseling cell should provide all information related to seats in each universities and guide students about the different opportunities available in each field. Along with this the members of this cell will help the students in setting their goals.

\section{Quality Teachers:}

By joke it is said by some one that industry rejected people come in teaching field. But it's not true in case of all those who are working in educational field. There are some teachers who have a passion to teach. Now days students have many sources to get study material of all the courses so they are not attracting towards the lecture rooms. They are two steps ahead than their teacher due to technological advancements. Teachers should continuously update their knowledge and indulge in research work. There should be regular seminars and inspirational talk to ensure that teachers are motivated to push students in right direction.

\section{Gap between Theory and Practice:}

There is a wide gap between what is taught in colleges and industry requirement. Most of the graduate programs in India do not meet the industry standards. Today's institutions/universities produce the degree holders who are not fit for recruitment. The cry of the companies is that they need to spend huge amount on training of these students to make them industry fit. The internship programme should be made mandatory in all professional colleges like management institutes and engineering institutes. Through this students will work in industry as an intern and will explored to the actual working environment.

\section{Conclusion:}

Government of India, Universities is taking efforts to enhance the quality of higher education. Still there is a long way up to bring our education system at par with the top universities of the world. For this there is a strong need of partnership between the stakeholders in educational system form elementary level to the higher education level. The present teaching-learning system ah veto be changed and practical knowledge has to be imparted among the students.

\section{References:}

1. http://indianexpress.com/article/education/whyindian-universities-are-not-in-global-ranking-2/

2. http://www.universityworldnews.com/article.php? story $=20171107143708776$

3. https://study.com/.../benchmarking-in-educationdef

4. http://www.infoprolearning.com/blog/advantagesand-disadvantages-of-moocs-massive-openonline-courses-for-learning/

5. https://en.wikipedia.org/wiki/Higher_education_in _India

6. http://www.guninetwork.org/articles/challengeshigher-education-21st-century

7. http://www.unesco.org/education/educprog/wche/ declaration_eng.htm

8. http://www.infoprolearning.com/blog/advantagesand-disadvantages-of-moocs-massive-openonline-courses-for-learning/ 